\title{
CORRESPONDENCE
}

\author{
Early treatment of myocardial \\ infarction in the community \\ B P Jones, MB; E R Somerville, MB . . . . . 1429 \\ Diagnosis of breast tumours \\ P R Simpson, MSC, and others........ 1430 \\ Terminal symptoms in children dying \\ suddenly and unexpectedly \\ J Grabinar, BM; J P Valentine, MRCGP; \\ J L Struthers, MB.............. \\ Maprotiline hydrochlor \\ M R Trimble, MRCPSYCH. \\ Changing social-class distribution of \\ heart disease \\ J J Segall, MRCP ; T R E Pilkington, FRCP : . \\ Frusemide and renal enzyme excretion \\ S M Harding, MB, and A J Munro, MRCP. . 1431 \\ Adverse reactions to intravenous \\ induction agents \\ J Watkins, PHD, and others......... 1431 \\ Deputising services \\ R A Dixon, PHD, and B T Williams, MD. . 1431 \\ Alpha-fetoprotein in the diagnosis of \\ hepatoma \\ P J Phillips and others. \\ How to raise funds \\ Josephine M Lomax-Simpson, MRCPSYCH 1432 \\ Intensive iron-chelation in \\ thalassaemia \\ C B Pignatti, MD, and P De Stefano, MD . 1432 \\ Naming of drugs \\ G A MacGregor, MD . . . . . . . . . 1433
}

How to appear on television

J J Slome, MB; D Morris, FRCP . . . . . . . 1433

Day hospitals

Marion Hildick-Smith, MD ......... 1433

Drug treatment of psychiatric patients

in general practice

P J Tyrer, MD...

Mortality and morbidity of reusing dialysers

J M Vandenbroucke, MD, and others.... 1434

Children with small stature

R R Gordon, FRCP................ 1434

Paraldehyde and plastic syringes

D P Addy, MRCP, and others . . . . . . . . . 1434

Breast-feeding as protection against

respiratory syncytial virus

L G Evans-Jones, MRCP, and others. . . . . 1434

Duodenal ulcers

D Craddock, FRCGP . . . . . . . . . . . . . . 1434

Increasing prevalence of breast-feeding

J R Oakley, MRCP............. 1435

Treatment of hydatidosis

M I Al-Moslih, PHD, and others. .

1435

Gamma-glutamyltransferase in ascitic

fluid in primary hepatoma

M Cortés-Rius, $\mathbf{M D}$, and others . . . . . . 1435

Data sheets and lactation

C D E Morris, MRCGP. . . . . . . . . . . . 1435

Serum trypsin concentrations in

diabetes mellitus

B M Frier, MRCP. .
Repeatability and reliability

M L Robinson, MRCP . . . . . . . . . . . . . 1436

Autoimmunity in juvenile diabetics and

their families

J I Mann, DM, and others. . . . . . . . . 1436

Tetracycline preparations for children

R J Rowlatt, MRCP............... 1436

Paget's disease of bone among British migrants to Australia

M J Gardner, PHD, and others......... 1436

Spinal cord transection in utero

I Blumenthal, MRCP................ 1437

Royal College of Surgeons of

Edinburgh: reform of fellowship

examinations

H Ellis, FRcs............... 1437

The Safety Net and preregistration

posts

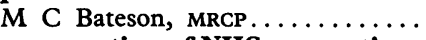

emuneration of NHS occupational

health physicians

J Gregory, MD.

Clinical medical officers

Gillian M Bryant, MFCM. .

Private practice and the reduction of pay-beds

D E Bolt, FRcs.

Dispute at Fife Area Laboratory

J D Barrie, $M D$, and others.........

Royal Medical Benevolent Fund

Christmas appeal

Sir Geoffrey Bateman, FRCS

Correspondents are urged to write briefty so that readers may be offered as wide a selection of letters as possible. So many are being received that the omission of some is inevitable. Letters must be signed personally by all their authors. As stated each week in "Instructions to authors" no letter will be acknowledged unless a stamped addressed envelope or an international reply coupon is enclosed.

\section{Early treatment of myocardial infarction in the community}

SIR,-The paper by Dr F G Dunn and his colleagues in the Glasgow University departments of cardiology and general practice $(21$ October, p 1143), reporting the inadequate preadmission treatment of myocardial infarction by general practitioners, is both sad and appalling. Sad in that it means that those GPs responsible have failed to hear and accept the cardiological facts of life and death so aggressively and evangelistically propounded over the past decade. ${ }^{1-4}$ Appalling in that the suffering of a patient with unrelieved cardiac pain is considerable and a journey under these circumstances without prior relief of pain, stabilisation of heart rate and rhythm, and control thereby of catecholamine release is not only not preventing cardiac arrest but actively promoting it.

Furthermore, if such GPs were to endeavour to attend such acute myocardial ischaemic incidents very much earlier than the average of 1.26 hours (range $0 \cdot 26-18$ ) quoted in the paper -in fact, immediately - they would be in time to experience the control of heart rate and rhythm disturbances leading to cardiac arrest and death occurring soon after the onset of the event. Such care activity is in reality both exciting and satisfying. It is, moreover, not difficult, being essentially the practical application of medical cardiology of quite limited content. GPs should refer to and practise these principles of coronary care or it will not be long before one of them will be involved in associated litigation. I am sure it would be construed that such knowledge and skill are to be expected from a GP today. The department of cardiology concerned is remiss in failing to communicate such knowledge and skill to the practitioners whom it serves. The shortage of a GP's medical time is referred to, and time is indeed grossly inadequate and abused in general practice. The control of impending cardiac arrest is, however, the prime call on GP time.

There is a belief among GPs that the monitoring hardware in a coronary care unit is essential for coronary care and that consequently getting the victim into such care is the prime essential. The coronary care unit is in reality for continuing care, unless it is prepared to become a mobile coronary care unit and take over the acute immediate care from the GP, as in Brighton. ${ }^{6}$

Many GPs appear to be of the opinion that powerful analgesic drugs are dangerous in the acute myocardial ischaemic event. In fact, the failure to use them or to use them inadequately is very dangerous indeed. If heroin is given slowly intravenously pain and anxiety are rapidly controlled. In many cases this is all that is required, although the GP should be capable of controlling persistent or subsequent disturbances of rate and rhythm. When so controlled such patients travel well, but many would consider that they should be moved under the monitoring care of suitably equipped GPs or the mobile coronary care unit.

I hope that this paper from Glasgow is not passed over but taken very seriously indeed.

BRIAN P JONES

Worsley,

Salford, Greater Mancheste

1 Partridge, J F, et al, The Acute Coronary Attack. London, Pitman Medical, 1975.

2 Julian, D G, Annals of Internal Medicine, 1968, 69, 607. Ocute Myocardial Infarction, ed D G Julian and M F Coronary Care in the Community, ed W A Colling, London, Croom Helm, 1977. sriggs, R' S, et al, British Medical fournal, 1976, 2,

SIR,-Dr F G Dunn and his colleagues (21 October, p 1143) assert that the principal reason for the failure of coronary care to fulfil our expectations is "the delay in admitting patients to the coronary care unit" and endorse Colling's suggestion ${ }^{1}$ that the general practitioner remain with the patient until the ambulance arrives and even accompany the patient to hospital.

Might it not be even more worth while were 